\title{
PENENTUAN RESPON DAN EFISIENSI IDENTIFIER UNTUK AKURASI DAN KETERTELUSURAN PENGUKURAN
}

\author{
Determination of Response and Efficiency of the Identifiers \\ for Measurement Accuracy and Traceability
}

\author{
Nazaroh, Iman Taufiq, Radhia Pradana \\ Pusat Teknologi Keselamatan dan Metrologi Radiasi - BATAN \\ Jl. Lebak Bulus Raya no. 49 Jakarta Selatan, DKI Jakarta, Indonesia \\ Email: nazaroh_s@batan.go.id
}

\begin{abstract}
Abstrak
Penentuan Respon dan Efisiensi Identifier untuk Akurasi dan Ketertelusuran Pengukuran. Berdasarkan Peraturan Kepala BAPETEN No.4/2013, dalam pemanfaatan tenaga nuklir harus mengutamakan prinsip prinsip proteksi radiasi agar pemanfaatannya aman bagi manusia dan lingkungan. Identifier adalah salah satu jenis Alat Ukur Radiasi (AUR) untuk memantau, mengukur paparan radiasi dalam besaran Laju Dosis Ekivalen Ambien, dan untuk mengidentifikasi jenis radionuklida. Untuk mendapatkan harmonisasi pengukuran, hasil pengukuran yang akurat, dan ketertelusuran, Identifier harus dikalibrasi dan diketahui responnya. AUR baru atau setelah perbaikan harus dikalibrasi setiap tahun berdasarkan Peraturan Kepala BAPETEN No. 1/2006. Berdasarkan IAEA-SRS No. 16/2000, AUR dapat dikalibrasi dengan Reference Instrument atau Reference Source. Ketiga jenis Identifier memiliki keistimewaan masing-masing sesuai dengan tujuan pemanfaatannya. Digunakan Reference Source gamma LMRI: ${ }^{137} \mathrm{Cs},{ }^{60} \mathrm{Co},{ }^{241} \mathrm{Am}$, dan ${ }^{152} \mathrm{Eu}$ pada SDD (Source Detector Distance) 0, 5; $10 ;. .60 \mathrm{~cm}$ untuk penentuan respon dan efisiensi tiga jenis Identifier. Pada makalah ini diperoleh respon dan efisiensi Identifier Exploranium GR-135, RIID SAM-945 dan InSpector-1000: kurva hubungan antara cps dan laju dosis ekivalen ambien pada variasi jarak dan invers kuadrat jarak, terhadap sumber gamma LMRI. Dengan dilakukannya kalibrasi ketiga jenis identifier ini, diharapkan terjadi harmonisasi pengukuran dan ketertelusuran. Respon dan efisiensi Identifier SAM-945 lebih besar/lebih sensitif dibandingkan dengan GR-135 dan InSpector1000, karena volume detektor SAM-945 lebih besar dibandingkan dengan kedua jenis Identifier lainnya. Dari studi ini, user dapat memilih identifier mana yang lebih sesuai untuk pemanfaatan di laboratorium, di tempat kerja, atau saat terjadi kecelakaan radiasi.
\end{abstract}

Kata kunci : Respon, Efisiensi, Identifier GR-135, SAM-945 (RIID), dan InSpector-1000.

\begin{abstract}
:
Determination of Response and Efficiency Identifiers for Measurement Accuracy and Traceability. Based on the Regulation of the BAPETEN Head No.4 / 2013, the utilization of nuclear power must prioritize the principles of radiation protection so that its utilization is safe for humans and the environment. Identifier is one type of Radiation Measuring Instrument (RMI) to monitor, measure radiation exposure in Ambient Equivalent Dose Rate, and can identify radionuclide types. To get harmonization in measurements and traceability, the Identifier must be calibrated.. Based on IAEA-SRS No. 16/2000, RMI can be calibrated with Reference Instrument or Reference Source. The three types of Identifiers have their respective features in accordance with the intended use. Gamma Reference Sources of LMRI $\left({ }^{137} \mathrm{Cs},{ }^{60} \mathrm{Co},{ }^{241} \mathrm{Am}\right.$, and $\left.{ }^{152} \mathrm{Eu}\right)$ was used for determining the response and efficiency of the Identifiers on Source Detector Distance (SDD) of 0,$5 ; 10 ; \ldots 60 \mathrm{~cm}$. In this paper, the response and efficiency of Exploranium GR-135, RIID SAM-945 and InSpector-1000 were obtained, especially for the relationship curve between cps and the ambient equivalent dose rate at various distances and inverse square distance to gamma LMRI. It was expected that harmonization of measurement and traceability will be achieved. The response and efficiency of the SAM-945 Identifier is greater than the GR-135 and InSpector-1000, because the detector volume of the SAM-945 is greater than others. From this study, the user can choose which identifier is more suitable for use in the laboratory, at work, or during a radiation accident.
\end{abstract}

Keywords : Response, efficiency, Identifier GR-135, SAM-945 (RIID), and InSpector-1000. 


\section{PENDAHULUAN}

Berdasarkan Peraturan Kepala BAPETEN No.4 pasal 27-32 (2013), dalam pemanfaatan tenaga nuklir harus mengutamakan azas/ prinsip prinsip proteksi radiasi agar pemanfaatannya aman bagi manusia dan lingkungan. Pemantauan paparan radiasi eksternal harus dilakukan di dalam dan di sekitar area kerja. Tujuannya untuk menilai kondisi tempat kerja dan paparan individu. Di samping itu untuk memastikan kondisi radiologis yang aman dan memuaskan di tempat kerja, dan untuk menyimpan catatan pemantauan dalam jangka panjang, baik untuk keperluan regulasi atau praktik kerja yang baik.

Peran laboratorium sangat menentukan dalam proses pengendalian dan penjaminan mutu hasil pengukuran. Menurut ISO: 17025 (2017), untuk mencapai kehandalan dan keakuratan dalam pengukuran, laboratorium harus menerapkan manajemen laboratorium yang berstandar internasional, yang mencakup sistem mutu dan teknis yang baik, dan pengukuran radiasi memerlukan ketertelusuran ke tingkat yang lebih tinggi.

Berdasarkan Peraturan Kepala BATAN No.14 pasal 140 (2013), dalam melaksanakan tugas sebagaimana dimaksud dalam Pasal 139, Pusat Teknologi Keselamatan dan Metrologi Radiasi menyelenggarakan fungsi: pelaksanaan penelitian dan pengembangan dan pelayanan di bidang metrologi radiasi.

Berdasarkan Peraturan Kepala BAPETEN No. 1 (2006) pada Bab III pasal 7 huruf d) dan e), Laboratorium Dosimetri Tingkat Nasional (LDTN) /PTKMR-BATAN memiliki tanggungjawab untuk mengembangkan prosedur dan metode kalibrasi AUR/peralatan pemantau dosis perorangan, dan keluaran sumber radiasi terapi dan mengembangkan prosedur dan standardisasi radionuklida.

Berdasarkan Peraturan Bapeten No.4 (013), keselamatan radiasi adalah tindakan yang harus dilakukan untuk melindungi pekerja, anggota masyarakat, dan lingkungan hidup dari bahaya Radiasi. Setiap instalasi nuklir, yang memanfaatkan radiasi dan sumber radioaktif untuk kegiatan litbang dan atau layanan radiasi, yang memiliki daerah pengendalian, hendaknya difasilitasi dengan AUR Identifier. Daerah Pengendalian adalah suatu daerah kerja yang memerlukan tindakan proteksi dan ketentuan keselamatan khusus untuk mengendalikan paparan normal atau mencegah penyebaran kontaminasi selama kondisi kerja normal dan untuk mencegah atau membatasi tingkat paparan potensial

Pada tahun 2019 ini telah dilakukan observasi terhadap 3 jenis AUR Identifier. Identifier adalah alat untuk memantau, mengukur paparan radiasi dalam besaran Laju Dosis Ekivalen Ambien, dan untuk mengidentifikasi jenis radionuklida dari paparan tersebut. Identifier banyak dimanfaatkan untuk program proteksi dan keselamatan radiasi terutama untuk keperluan daerah Pengendalian.

Berdasarkan IAEA-SRS-16 (2000), AUR dapat dikalibrasi dengan Reference Instrument (alat rujukan) atau Reference Source (sumber rujukan). Reference Instrument haruslah standar sekunder yang dikalibrasi dengan standar utama oleh laboratorium primer nasional atau di laboratorium rujukan yang diakui, yang memiliki standar yang sesuai. Reference Source harus merupakan sumber standar sekunder yang dikalibrasi dengan standar primer oleh laboratorium primer nasional atau di laboratorium rujukan yang diakui, yang memiliki standar yang sesuai.

Pada makalah ini disajikan penentuan respon dan efisiensi Identifier Exploranium GR135, RIID SAM-945 dan InSpector-1000 menggunakan Reference Source LMRI : ${ }^{137} \mathrm{Cs}$, ${ }^{60} \mathrm{Co},{ }^{152}$ Eu dan ${ }^{241} \mathrm{Am}$. Pengamatan respon dan efisiensi dilakukan terhadap jarak dan invers kuadrat jarak, kurva hubungan antara cps dan laju dosis ekivalen., dan observasi terhadap jenis radionuklida yang dapat diidentifikasi.

Bila Identifier ini digunakan untuk memantau, mengukur paparan radiasi maka akan diperoleh informasi laju dosis ekivalen, jenis radionuklida dan aktivitas radinuklida tersebut. Dari studi ini, user dapat memilih identifier mana yang lebih sesuai untuk pemanfaatan di laboratorium, di tempat kerja, atau saat terjadi kecelakaan radiasi.

\section{TINJAUAN PUSTAKA}

\section{Identifier Exploranium SAIC GR-135}

Dari Manuallinstruction of Exploranium ${ }^{T M}$ GR135 The Identifier, (2005), dan (2006), Identifier Exploranium SAIC GR-135 (Gambar 1a) adalah AUR yang dilengkapi dengan sakelar mode otomatis dan mode manual, memori data untuk survei dan data spektral, fungsi laju dosis 
ekivalen ambien, $H^{*}(10)$, memiliki kemampuan untuk memonitor ada tidaknya zat radioaktif, dan dapat mengidentifikasi jenis radionuklida dan aktivitas.

Identifier Exploranium GR-135 merupakan alat pemantau radiasi, menggunakan detektor $\mathrm{Nal}(\mathrm{TI})$ berukuran volume $65 \mathrm{~cm}^{3}$ (diameter 38 $\mathrm{mm} \times$ panjang $27 \mathrm{~mm}$ ), dilengkapi dengan digital MCA (Multi Channel Analyzer), dengan 1024 channel, mampu mengamati radionuklida dengan rentang energi $0,02-3 \mathrm{MeV}$, FWHM $9 \%$ pada puncak ${ }^{137} \mathrm{Cs}$, memiliki kemampuan untuk mencari dan menemukan bahan radioaktif tertentu seperti : ${ }^{235} \mathrm{U},{ }^{233} \mathrm{U}$ dan ${ }^{239} \mathrm{Pu}$. Koefisien kalibrasi untuk Mode ASSAY telah ditetapkan oleh SAIC Exploranium dan tidak dapat diubah oleh pengguna.

Mode otomatis hanya untuk fungsi search dan assay. GR-135 harus terhubung ke kabel daya 12V (Docking Station /DS) saat tidak digunakan, setidaknya sekali setiap 24 jam untuk stabilisasi. DS memiliki sumber ${ }^{137} \mathrm{Cs}$ (9 $\mathrm{kBq})$ bawaan untuk membuat stabilisasi tetapi user harus menempatkan sumber ${ }^{137} \mathrm{Cs}$ pada lubang yang disediakan di booting pelindung kuning. Stabilisasi terjadi ketika terhubung ke kabel daya $12 \mathrm{~V}$.

\section{SAM-945 Radioisotope Identifier Device (RIID)}

Dari SAM 945 (2016), Portable Isotope Identifier Instruction Manual, SAM-945 RIID (Gambar 1b.) adalah Radio-Isotope Identifier Device buatan Barkeley Nucleonic, untuk mendeteksi adanya paparan radiasi, dengan besaran Laju Dosis Ekivalen Ambien, $\mathrm{H}^{*}(10)$ dengan satuan $\mu \mathrm{Sv} / \mathrm{h}$ dan mengidentifikasi radionuklida, dengan alat bacanya Motorola Moto G, terpisah dari detektornya. Alat bacanya berupa fitur baru yang memanfaatkan teknologi ponsel modern (Smartphone). Tersedia prosesor yang mengelola koleksi spektral dan dapat mengidentifikasi isotop sebanyak 115 isotop dengan kemungkinan ekspansi hingga 393 isotop.

SAM-945 dirancang untuk memenuhi standar ALARA dengan menggunakan teknologi smartphone. SAM-945 digunakan untuk pengukuran jarak dekat dengan sumber radiasi, untuk mendapatkan data statistik yang baik, namun operator dapat berjarak 20 kaki dari SAM-945 dan sumber radioaktif. Detektor meneruskan data ke smartphone melalui
Bluetooth. Smartphone menyediakan tampilan yang mudah dibaca, memberi tahu user tentang identitas dan tingkat radionuklida yang ada. Smartphone SAM 945 juga dapat menggunakan layanan pencari lokasi untuk secara terusmenerus mengirimkan lokasi GPS untuk pemetaan data radiasi. Setelah menyelesaikan survei, data dapat diunduh dari smartphone ke PC. SAM 945 dirancang dengan detektor natrium iodida $\mathrm{Nal}(\mathrm{TI})$ : $(3 \times 3)$ inchi, untuk memberikan sensitivitas yang tinggi, dan dapat mengidentifikasi isotop. Sistem ini juga tersedia dengan tabung GM untuk deteksi neutron.

\section{InSpector-1000}

Dari InSpector TM 1000 (2017), InSpector1000 (Gambar 1c.) adalah salah satu jenis identifier dengan penganalisa salur ganda (MCA) portable, diproduksi oleh Divisi Spektroskopi. InSpector-1000 dilengkapi dengan probe Nal yang cukup stabil untuk mengidentifikasi isotop, menggunakan real time, dan mode Gamma Locator, untuk menentukan lokasi sumber. Inspector-1000 didesain sedemikian rupa sehingga dapat didekontaminasi, kokoh, dan anti tumpahan. Instrumen genggam ini dioperasikan dengan baterai dengan LCD warna beresolusi tinggi terlihat siang dan malam, dengan daya tahan baterai hingga 9 jam.

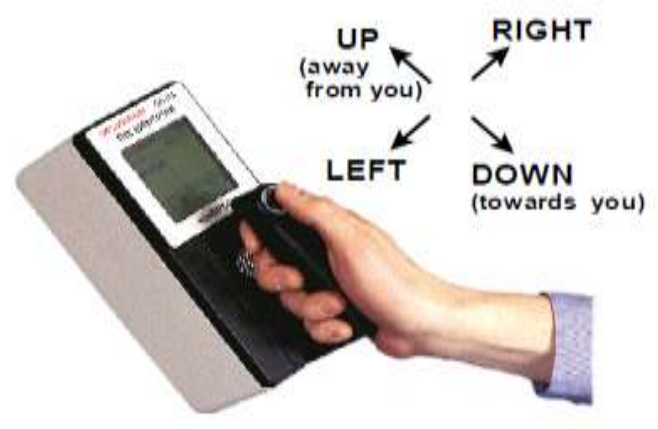

Gambar 1a. Identifier GR-135 [Exploranium ${ }^{\mathrm{TM}}$ GR-135 The Identifier (2005)]. 




Gambar 1b. Identifier SAM-945 [SAM 945 (2016)].
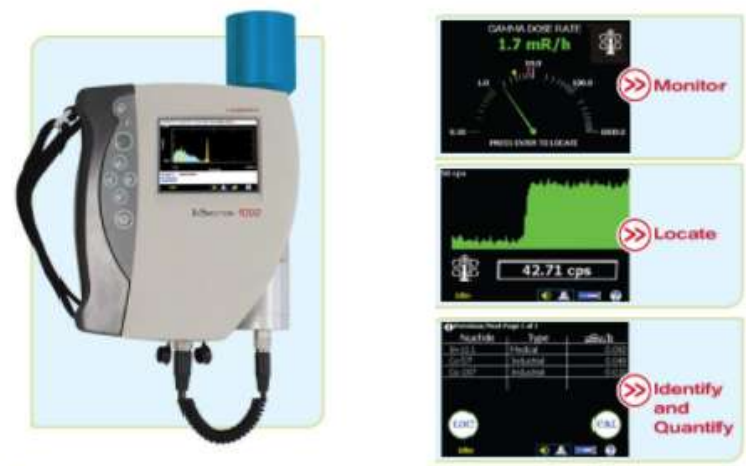

Gambar 1c. Identifier InSpector-1000 dengan tampilan MCA [InSpector ${ }^{\mathrm{TM}} 1000$ (2017)],

\section{METODE PENELITIAN}

Untuk mendapatkan harmonisasi pengukuran dan hasil pengukuran yang akurat, serta ketertelusuran, identifier harus dikalibrasi dan diketahui responnya berdasarkan Peraturan Kepala BAPETEN No. 1/2006.

Kalibrasi Alat Ukur Radiasi (AUR) dapat dilakukan dengan dua metode yaitu dengan reference instrument [alat rujukan] atau reference source [sumber rujukan], berdasarkan SRS-IAEA 16/2000.

Jika Identifier dikalibrasi dengan Reference Instrument, PTKMR menggunakan Calibrated Ionization Chamber (CIC) 600cc yang dirangkai dengan Dosimeter Farmer atau electrometer lainnya, yang memiliki faktor kalibrasi, $\mathrm{N}_{\mathrm{k}}$ dengan satuan $[\mu \mathrm{Gy} / \mathrm{nC}$ ] (traceable ke laboratorium Primer/SSDL IAEA). CIC digunakan untuk mengukur berkas gamma, OB-
85 di laboratorium Kalibrasi AUR-Gamma, PTKMR-BATAN, pada TPH (Temperature, Pressure, dan Humidity) standar, maka akan menghasilkan bacaan, $\mathrm{M}$ dengan satuan [nC/s], Berdasarkan IAEA-SRS 16 (2000), Nazaroh (2010, 2016), Susilowati, P.dkk, (2011), Guide ST 1.9, (2016), Laju Kerma udara, $K_{u}$ dapat ditentukan dengan persamaan (1).

$$
K_{u}=N_{k} x M x K_{P T} \ldots\left[\begin{array}{ll}
h G y \\
h
\end{array}\right](1)
$$

$\mathrm{K}_{\mathrm{u}}$ dikonversikan menjadi laju dosis ekivalen ambien, $H^{*}(10) \quad[\mu \mathrm{Sv} / \mathrm{h}]$ dengan mengalikan faktor konversi, h (bergantung pada energi radiasi dan sudut datang radiasi).

$$
H^{*}(10)=K_{u} \times h \ldots[\mu S v / h](2)
$$

Jika bacaan Identifier, $\mathrm{H}^{*}{ }_{\text {id }}$ dengan satuan $[\mu \mathrm{Sv} / \mathrm{h}]$, maka faktor kalibrasi, $\mathrm{N}_{\mathrm{ld}}$ tidak berdimensi, dihitung dengan persamaan (3),

$$
\mathrm{N}_{\mathrm{id}}=\frac{H^{*}(10)}{H^{*} i d} .,, . .(3)
$$

Respon. $\mathrm{R}$, dari Identifier adalah hasil bagi indikasi instrumen, $\mathrm{H}_{\text {id }}$ dan nilai konvensional sebenarnya, $H^{*}(10)$, disajikan pada persamaan (4) Respons $R$ bervariasi, bergantung pada distribusi spektral (energi) dan sudut datang radiasi.

$$
\mathrm{R}=\frac{H^{*}{ }_{i d}}{H^{*}(10)}
$$

Jika Identifier dikalibrasi dengan Reference Source LMRI $\left({ }^{137} \mathrm{Cs},{ }^{60} \mathrm{Co},{ }^{241} \mathrm{Am}\right.$ dan $\left.{ }^{152} \mathrm{Eu}\right)$ (Gambar 2), maka aktivitas reference source saat pengukuran [dps] diluruhkan dari Reference Time (RT) dengan persamaan (5).

Indikasi bacaan Identifier, [cps] dan $\mathrm{Y}$ adalah yield dari Reference source, maka berdasarkan NCRP Report No. 58 (1986), efisiensi, $\varepsilon\left(\mathrm{E}_{1}\right)$ dapat dihitung dengan persamaan (6). Efisiensi detektor bergantung pada energi, jarak, dan geometri sumber.

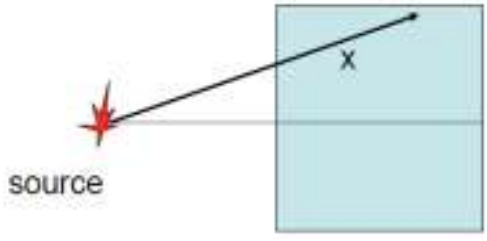

Gambar 2. Reference Source dan detektor 


$$
A_{\mathrm{t}}=A_{0} \mathrm{Xe}^{-0,69 \mathrm{axt} / \mathrm{T}} \ldots \ldots \ldots[\mathrm{dps}](5)
$$

$\begin{array}{cl}\mathrm{A}_{\circ} & \begin{array}{l}\text { : aktivitas awal dari reference source } \\ \mathrm{A}_{\mathrm{t}}\end{array} \\ \mathrm{t} & \begin{array}{l}\text { : Aktivitas reference source saat } \mathrm{t} \\ \text { (saat pengukuran) }\end{array} \\ \mathrm{t} & \begin{array}{l}\text { : perbedaan waktu antara Reference } \\ \text { Time dengan tanggal pengukuran. }\end{array} \\ \mathrm{T} & \text { : waktu paro dari reference source }\end{array}$

$$
a\left(E_{i}\right)=\frac{c p s}{d p s x Y\left(E_{i}\right)}
$$

$\varepsilon(\mathrm{E} \imath)$ : efisiensi Identifier pada energi $(\mathrm{Ei})$

cps : count per second Identifier

dps : disintegrasi persecond (aktivitas)

$\mathrm{Y}(\mathrm{Ei})$ : yield reference source pada energi $(\mathrm{Ei})$

Kesalahan intrinsik relatif, $\mathrm{K}_{\mathrm{i}}$ (dinyatakan dalam \%) didefinisikan sebagai hasil bagi dari kesalahan indikasi, $\mathrm{H}^{*}(10)-\mathrm{H}^{*}$ id, dengan nilai konvensional, $\mathrm{H}^{*}(10)$ (sebenarnya) $\times 100 \%$.

$$
\mathrm{K}_{\mathrm{i}}(\%)=\frac{H^{*}(10)-H^{*} i d}{H^{*}(10)} \times 100 \%
$$

\section{Peralatan dan Bahan}

Peralatan yang digunakan pada litbang ini disajikan pada Gambar 1a, 1b dan 1c. Sedangkan Reference Source yang digunakan adalah LMRI, disajikan pada Gambar 3, dan setting pengukuran disajikan pada Gambar 4.

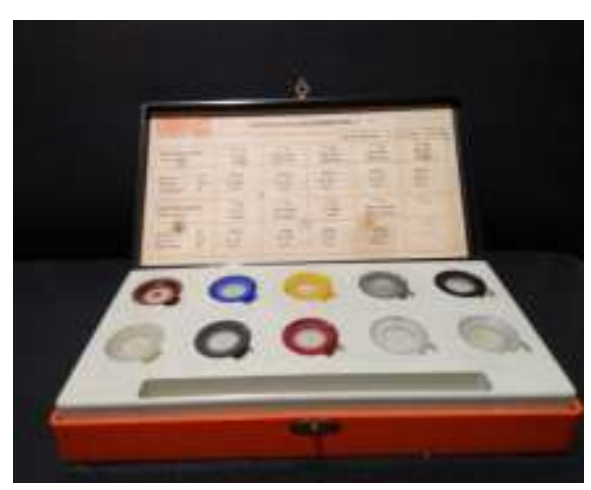

Gambar 3. Reference source LMRI

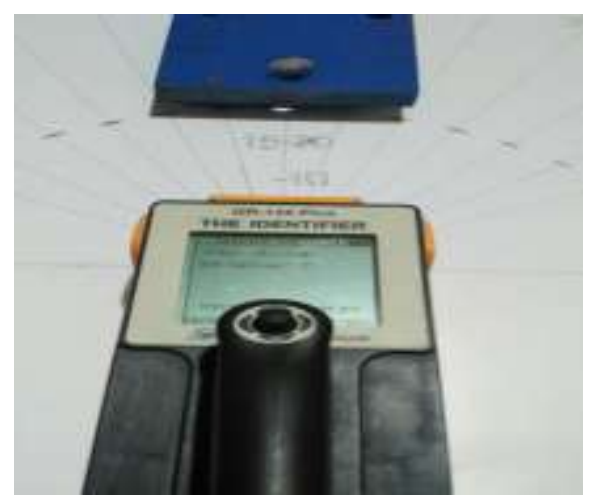

Gambar 4. Setting pengukuran Respon GR-135

Telah dipelajari respon dan efisiensi 3 jenis Identifier (GR-135, SAM-945 RIID, dan InSpector-1000) terhadap 4 sumber titik gamma LMRI : ${ }^{137} \mathrm{Cs},{ }^{60} \mathrm{Co},{ }^{241} \mathrm{Am}$ dan ${ }^{152} \mathrm{Eu}$ (Gambar 5a, $5 \mathrm{~b}$ dan $5 \mathrm{c}$.) pada variasi SDD $0 ; 5 ; 60 \mathrm{~cm}$ dan efisiensinya disajikan pada Tabel 1 dan Tabel 2.

Tabel 1. Reference Source dan Efisiensi Identifier

\begin{tabular}{cccccccccc}
\hline No & RS & $\mathbf{A}_{\mathbf{o}}$ (Bq) & Ref.Time & $\begin{array}{c}\text { Waktu } \\
\text { Paro }\end{array}$ & $\begin{array}{c}\text { Energi } \\
\text { (keV) }\end{array}$ & Yield & $\begin{array}{c}\text { Efisiensi } \\
\text { GR-135 }\end{array}$ & $\begin{array}{c}\text { Efisiensi } \\
\text { SAM-945 }\end{array}$ & $\begin{array}{c}\text { Efisiensi } \\
\text { (Insp1000) }\end{array}$ \\
\hline $\mathbf{1}$ & ${ }^{137} \mathrm{Cs}$ & 472.120 & 15 Jan.80 & 30,2 th & 661,6 & 0,944 & 0,0108 & 0,0252 & 0,0163 \\
& & & & & & & & & \\
$\mathbf{2}$ & ${ }^{60} \mathrm{Co}$ & 458.800 & 15 Jan.80 & 5,27 th & 1.253 & 0,9999 & 0,0669 & 0,1963 & 0,1269 \\
$\mathbf{3}$ & ${ }^{152} \mathrm{Eu}$ & 560.920 & 4 Jan.80 & 13,1 th & 344 & 0,276 & 0,1235 & 0,3531 & 0,2062 \\
$\mathbf{4}$ & ${ }^{241} \mathrm{Am}$ & 469.160 & 15 Jan.80 & 432 th & 59,5 & 0,780 & 0,0095 & 0,0267 & 0,0128 \\
& & & & & & & & \\
\hline
\end{tabular}


Tabel 2. Respon ketiga jenis Identifier terhadap Reference Source LMRI pada SDD $=5 \mathrm{~cm}$

\begin{tabular}{cccc}
\hline \multirow{2}{*}{ RN } & \multicolumn{3}{c}{ Respon } \\
\cline { 2 - 4 } & GR-135 & SAM-945 & InSpector-1000 \\
\hline${ }^{13} \mathrm{Cs}$ & $\mathrm{cps}=956^{*} \mathrm{H}+55$ & $\mathrm{cps}=3123^{*} \mathrm{H}+58$ & $\mathrm{cps}=1958^{*} \mathrm{H}+172$ \\
${ }^{60} \mathrm{Co}$ & $\mathrm{cps}=564^{*} \mathrm{H}+66$ & $\mathrm{cps}=1377^{*} \mathrm{H}+223$ & $\mathrm{cps}=1440^{*} \mathrm{H}+147$ \\
${ }^{241} \mathrm{Am}$ & $\mathrm{cps}=7877^{*} \mathrm{H}-670$ & $\mathrm{cps}=31076^{*} \mathrm{H}-3872$ & $\mathrm{cps}=21524^{*} \mathrm{H}-813$ \\
${ }^{152} \mathrm{Eu}$ & $\mathrm{cps}=1389^{*} \mathrm{H}-1.5$ & $\mathrm{cps}=2345^{*} \mathrm{H}+78$ & $\mathrm{cps}=3088^{*} \mathrm{H}+17$ \\
\hline
\end{tabular}

$\mathrm{H}$ : Laju dosis ekivalen ambien, [ $\mu \mathrm{Sv} / \mathrm{h}]$

cps $=$ count per second

\section{HASIL DAN PEMBAHASAN}

Sumber gamma yang digunakan untuk kalibrasi atau menentukan respon Identifier adalah Reference standard source buatan LMRI. Reference Source ini juga dapat digunakan untuk kalibrasi efisiensi alat lain seperti : system pencacah spectrometer gamma. Karena waktu paronya panjang, sumber standar ini dapat digunakan puluhan tahun bahkan ratusan tahun, seperti ${ }^{241} \mathrm{Am}\left(\mathrm{T}_{1 / 2}=432\right.$ tahun).

Reference Source ini merupakan sumber standar sekunder yang dikalibrasi dengan standar primer oleh laboratorium primer nasional atau di laboratorium rujukan yang diakui, yang memiliki standar yang sesuai.

Pada Gambar 5a, 5b dan 5c, disajikan Respon Identifier GR-135 plus, SAM-945 dan inSpector 1000 terhadap sumber gamma LMRI : ${ }^{241} \mathrm{Am},{ }^{152} \mathrm{Eu},{ }^{137} \mathrm{Cs}$, dan ${ }^{60} \mathrm{Co}$. Responnya linier. Dari ketiga gambar tersebut, diperoleh informasi bahwa RIID SAM-945 adalah identifier yang paling sensitive, karena responnya terhadap radionuklida (cps) paling tinggi. Respon ketiga jenis Identifier terhadap sumber gamma tersebut paling tinggi adalah terhadap ${ }^{241} \mathrm{Am}$, kemudian ${ }^{152} \mathrm{Eu}$, lalu ${ }^{137} \mathrm{Cs}$, dan terakhir terhadap ${ }^{60} \mathrm{Co}$.

Aktivitas saat pengukuran, paling tinggi adalah ${ }^{241} \mathrm{Am}$, karena waktu paronya 432 tahun dan waktu paro terpendek adalah ${ }^{60} \mathrm{Co}(5,27$ tahun). Kurva respon tersebut diperoleh dari data pengukuran pada SDD $=5 \mathrm{~cm}$ hingga 60 $\mathrm{cm}$. Semakin dekat jarak sumber ke detektor, atau semakin besar aktivitas sumber, akan semakin besar laju dosis ekivalen yang akan ditimbulkan. Dari kurva ini kita dapat menghitung paparan radiasi (laju dosis ekivalen) untuk radionuklida ${ }^{241} \mathrm{Am},{ }^{152} \mathrm{Eu},{ }^{137} \mathrm{Cs}$, dan ${ }^{60} \mathrm{Co}$, pada aktivitas dan jarak tertentu.

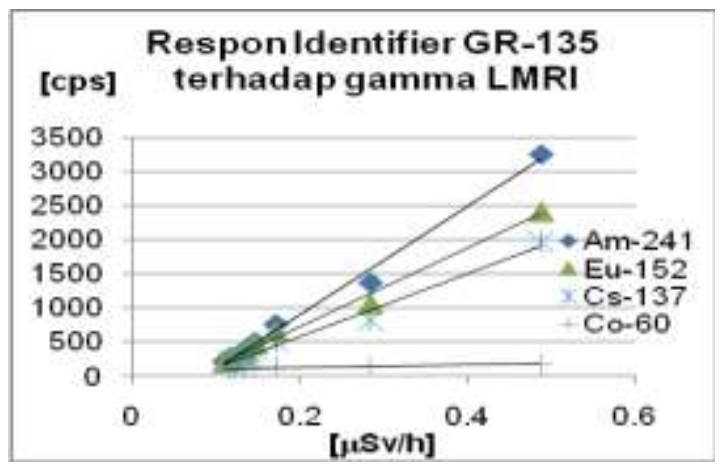

Gambar 5a. Respon GR-135 terhadap sumber gamma LMRI

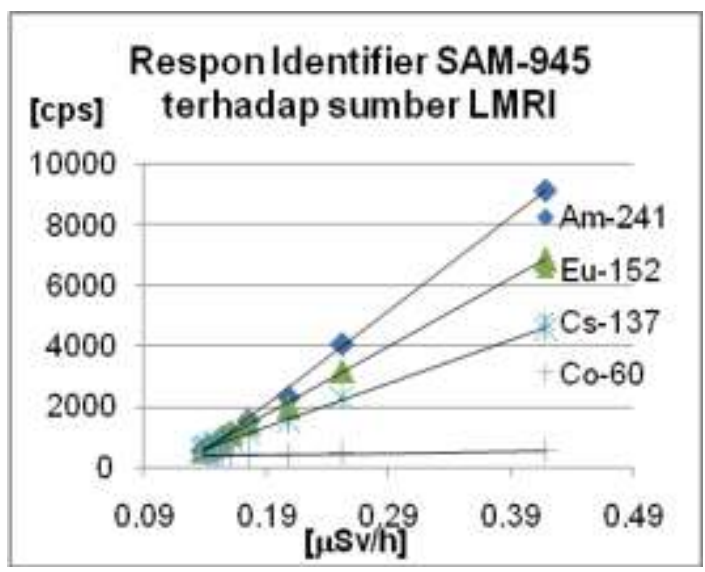

Gambar 5b. Respon SAM-945 terhadap sumber gamma LMRI

Jika kita bandingkan Gambar 5a, 5b dan 5c, Respon Identifier SAM-945 terhadap radionuklida ${ }^{241} \mathrm{Am}$ memberikan bacaan cps paling besar dibandingkan Identifier lainnya, hal ini disebabkan karena volume detektor AM-945 lebih besar dibandingkan dengan kedua detektor lainnya. 


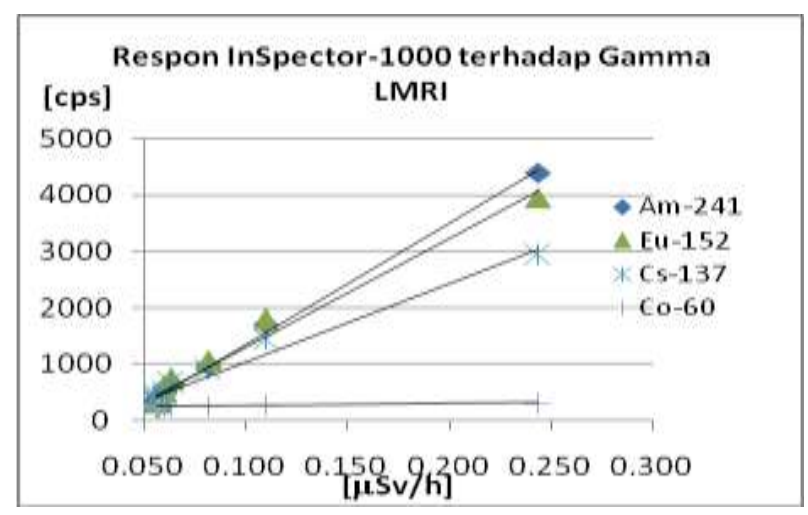

Gambar 5c. Respon InSpector-1000 Terhadap sumber gamma LMRI

Pada Tabel 1 (terlampir) disajikan sumber acuan LMRI dan efisiensi ketiga jenis identifier. Diperoleh efisiensi Identifier GR-135 pada SDD $5 \mathrm{~cm}$, disajikan pada kolom 8, efisiensi Identifier SAM-945 pada kolom 9, dan efisiensi Inspector-1000 pada kolom 10.

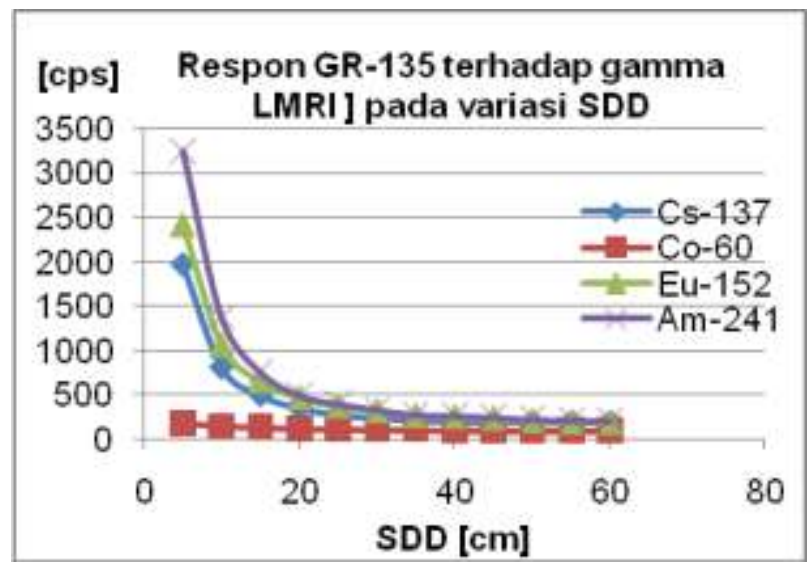

Gambar 6a. Respon GR-135 terhadap Gamma pada variasi SDD

Efisiensi SAM-945 relatif lebih besar dibandingkan dengan kedua jenis identifier lainnya artinya bahwa SAM-945 lebih sensitive dibandingkan dengan Inspector-1000 dan GR-135 karena volume detektor SAM-945 lebih besar dari kedua identifier tersebut.

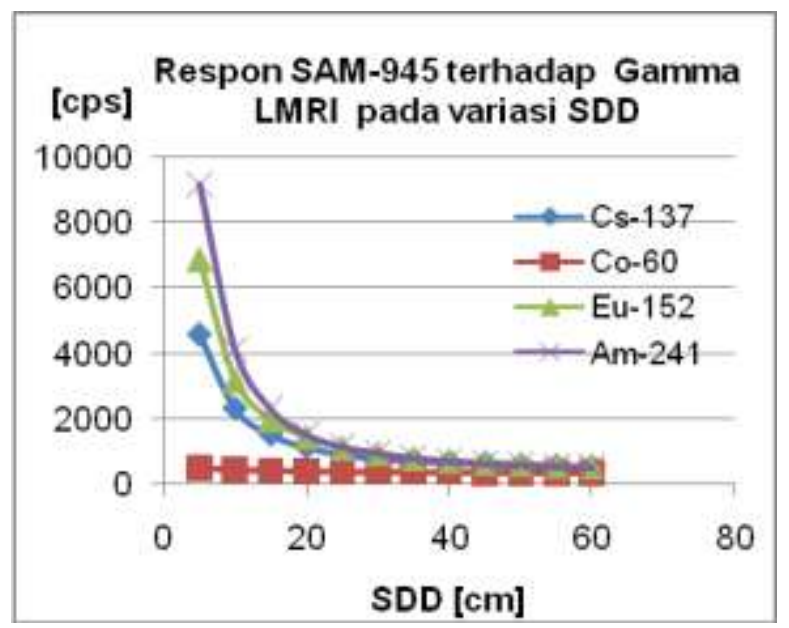

Gambar 6b. Respon SAM-945 terhadap Gamma LMRI pada variasi SDD



Gambar 6c. Respon InSpector-1000 terhadap Gamma LMRI pada variasi SDD

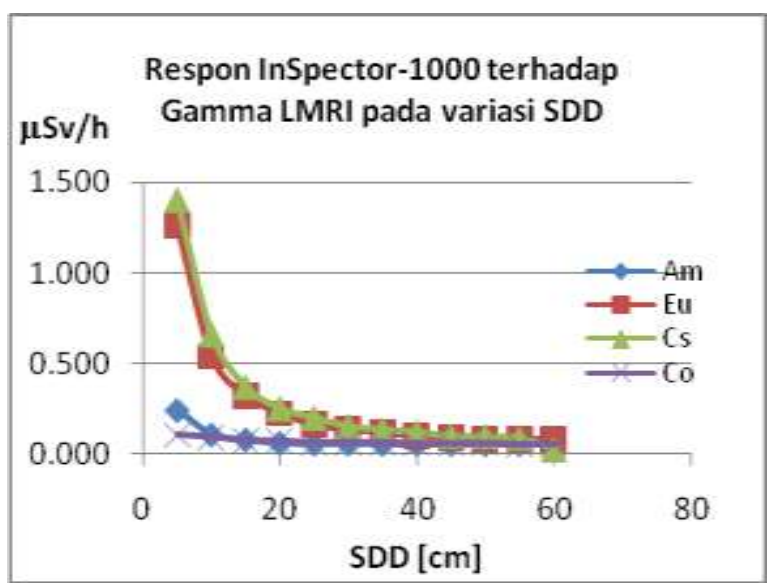

Gambar 6d. Respon InSpector-1000 terhadap Gamma LMRI pada variasi SDD 


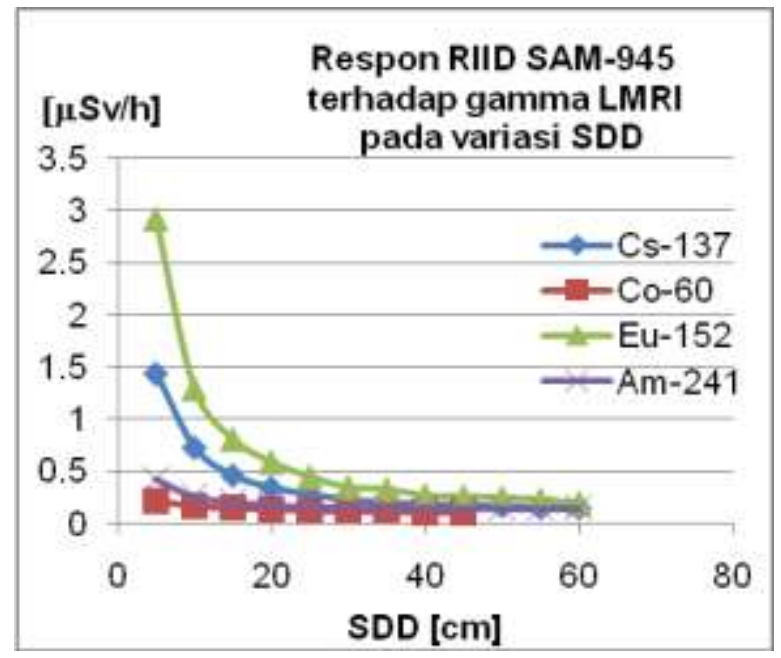

Gambar 6e. Respon SAM-945 terhadap Gamma LMRI pada variasi SDD

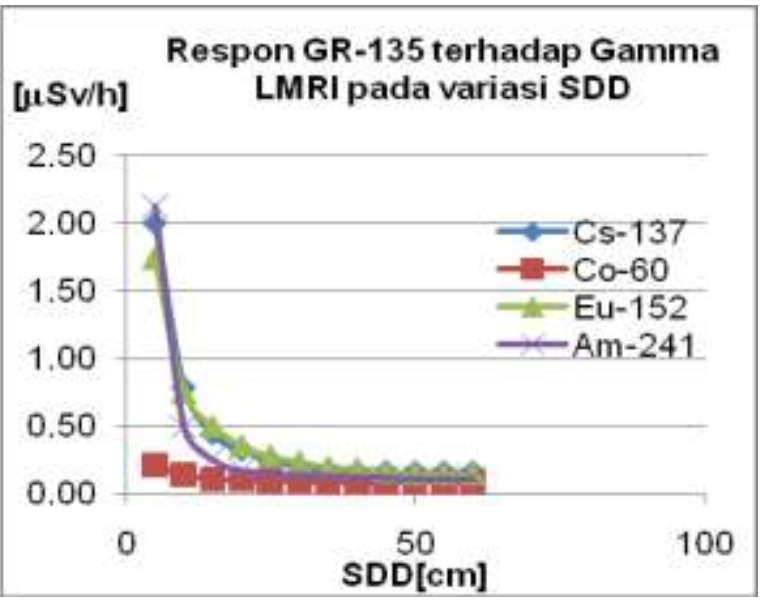

Gambar 6f. Respon GR-135 terhadap Gamma LMRI pada variasi SDD

Respon ketiga jenis Identifier terhadap Laju cacah (cps) disajikan pada Gambar 6a,6b, 6c dan respon terhadap laju dosis ekivalen ambient $[\square \mathrm{Sv} / \mathrm{h}]$ untuk sumber titik LMRI pada variasi SDD, disajikan pada Gambar 6d,6e, dan 6f, Diperoleh hasil, Laju cacah gamma [cps] dan laju dosis ekivalen ambient [ $\square \mathrm{Sv} / \mathrm{h}]$, menurun secara eksponensial dengan bertambahnya SDD.

Hal ini memberikan informasi kepada kita apabila paparan radiasi di tempat kerja sangat tinggi, maka pengukuran dapat dilakukan dengan jarak yang lebih jauh agar paparan radiasinya turun secara eksponensial. Apabila pengukuran terlalu dekat dengan sumber dan paparan radiasinya tinggi, maka identifier akan memberikan bunyi alarm dan peringatan warna merah pada skala pengukurannya, karena deadtimenya tinggi sehingga hasil pengukurannya tidak akurat.

Dalam prinsip proteksi radiasi, laju paparan atau laju dosis ekivalen ambien dapat berkurang dengan pengaturan faktor jarak. Semakin dekat jarak sumber ke detektor semakin besar paparannya dan sebaliknya, semakin jauh dari sumber, maka paparan radiasi menjadi berkurang. Semakin dekat pekerja radiasi dengan sumber radiasi maka paparan radiasi yang diterimanya akan semakin besar.

Seorang pekerja radiasi yang berada di dalam medan radiasi akan menerima dosis radiasi yang besarnya sebanding dengan jarak dan lamanya berada di dalam medan radiasi. Semakin dekat dan lama seseorang berada di medan radiasi tersebut, akan semakin besar dosis radiasi yang diterimanya, demikian pula sebaliknya.

Dosis radiasi yang diterima oleh pekerja selama di dalam medan radiasi dapat dirumuskan sebagai berikut:

$D=\Xi x t \ldots$ (8) $\mu G y$

D : dosis yang diterima pekerja ( $\mu \mathrm{Gy})$

Đ : laju dosis serap $\mu \mathrm{Gy} / \mathrm{h}$

t : lamanya berada dalam medan radiasi,

Faktor jarak berkaitan erat dengan Intensitas (I) radiasi. Intensitas radiasi pada suatu titik akan berkurang berbanding terbalik dengan kuadrat jarak antara titik tersebut dengan sumber radiasi.

Intensitas radiasi didefinisikan sebagai jumlah radiasi yang menembus luas permukaan (dalam cm2) per satuan waktu (s). Seperti yang terlihat pada Gambar 7. Intensitas radiasi pada permukaan bola dengan jari-jari $R$

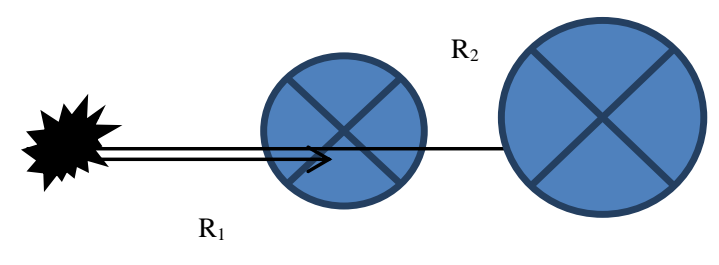

Sumber Radiasi Permukaan detektor/bola

Gambar 7. Intensitas radiasi pada permukaan bola dengan jari-jari $R$ 
Intensitas radiasi pada permukaan bola dengan jari-jari $R_{1}$ dan $R_{2}$ masing-masing adalah:

$I_{1}=\frac{P}{4 \pi R_{1}^{2}}$

$I_{2}=\frac{p}{4 \pi R_{2}^{2}}$

Dari persamaan 9 dan 10 dapat diperoleh hubungan sebagai berikut:

$I_{1}: I_{2}=\frac{1}{R_{1}^{2}}: \frac{1}{R_{2}^{2}}$

Dari persamaan (11) terlihat bahwa intensitas radiasi, I baik dalam bentuk cps atau laju dosis ekivalen ambien pada suatu titik berbanding terbalik dengan kuadrat jarak titik tersebut terhadap sumber radiasi (Lihat Gambar 8a, 8b, dan 8c). Laju dosis ekivalen ambien naik dengan naiknya invers kuadrat SDD atau berbanding lurus/linier dengan invers kuadrat SDD.

$D_{2}=\frac{R_{1}^{2}}{R_{2}^{2}} D_{1}$

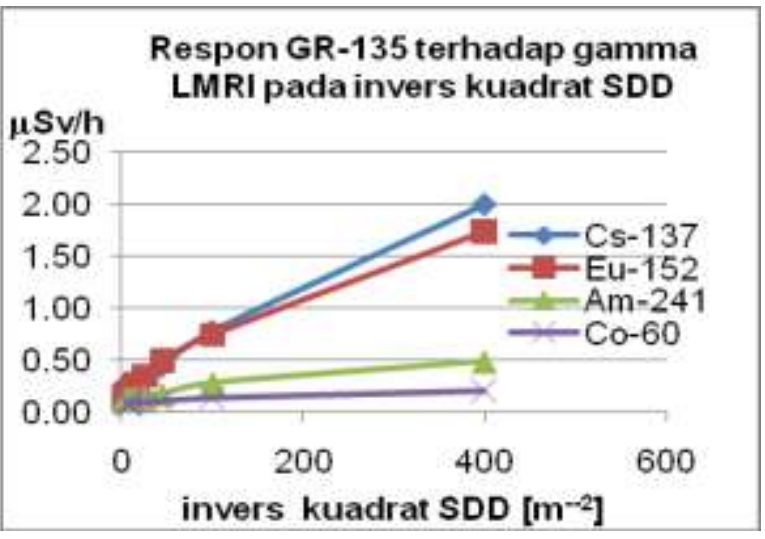

Gambar 8a. Respon GR-135 terhadap Gamma pada invers kuadrat SDD

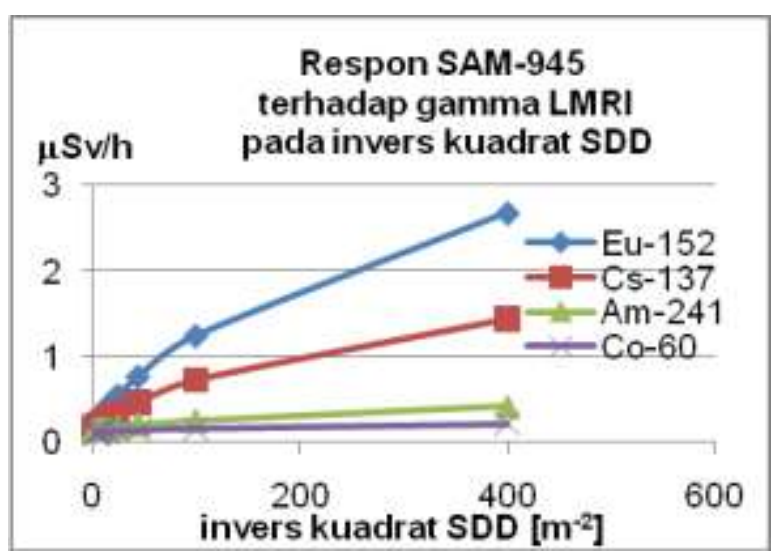

Gambar 8b. Respon SAM-945 terhadap Gamma pada invers kuadrat SDD

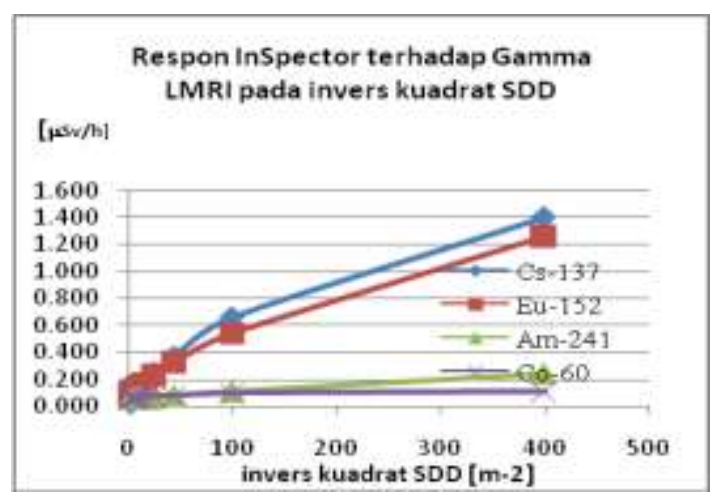

Gambar 8c. Respon InSpector-1000 terhadap Gamma pada invers kuadrat SDD

Pada Tabel 2 (terlampir), Respon Identifier SAM-945 terhadap 241Am paling tinggi/sensitive. Untuk $H^{*}(10)=1 \square \square \mathrm{Sv} / \mathrm{h}$, memberikan cacahan $=31076 * \mathrm{H}-3872=27.204$ [cps].

Untuk ketiga jenis Identifier, respon tertinggi adalah terhadap 241Am, karena aktivitas $241 \mathrm{Am}$ masih cukup besar, waktu paronya 432 tahun. Respon terendah untuk ketiga jenis Identifier adalah terhadap 60Co, karena aktivitasnya paling kecil saat ini , dikarenakan waktu paronya paling pendek $(5,27$ tahun). Untuk $1 \square \mathrm{Sv} / \mathrm{h}$ 60Co, SAM945 akan memberikan respon sebesar 1599 [cps].

Dari persamaan di dalam Tabel 2. dapat diperkirakan aktivitasnya apabila laju dosis ekivalennya diketahui dari pengukuran.

Dari ketiga jenis Identifier, GR-135 plus paling kurang sensitive dibandingkan dengan InSpector-1000 dan SAM-945, terbukti dari persamaan yang ditampilkan pada Tabel 2. Hal 
ini disebabkan karena volume detektor tersebut paling kecil.

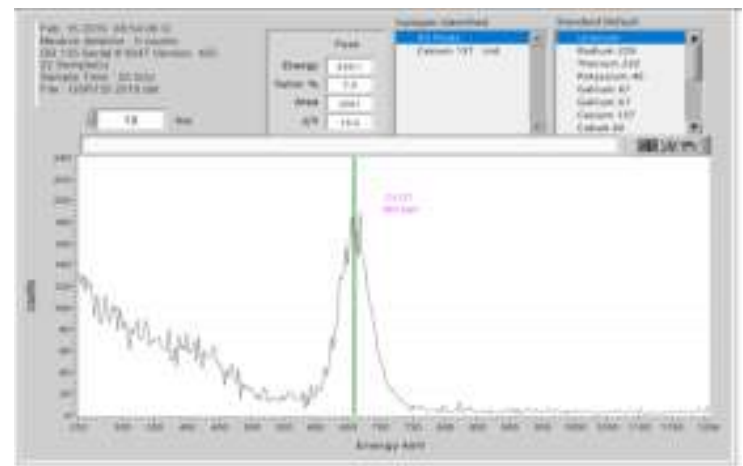

Gambar 9a. Tampilan ${ }^{137}$ Cs pada GR-135

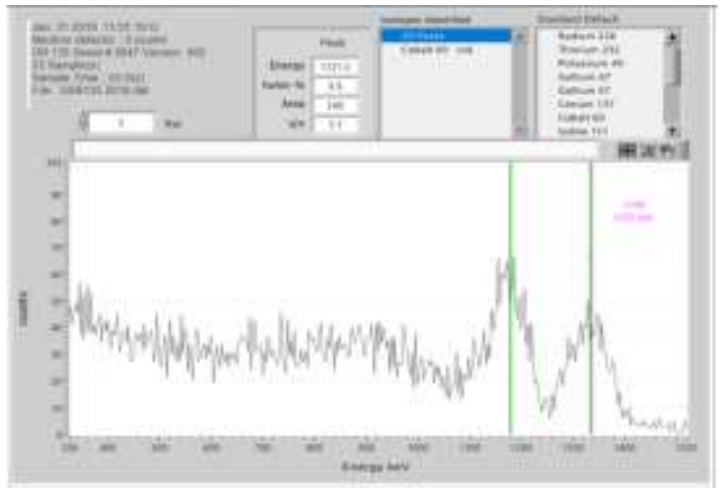

Gambar 9b. Tampilan ${ }^{60} \mathrm{Co}$ pada GR-135

Pada Gambar 9a dan 9b disajikan tampilan ${ }^{137} \mathrm{Cs}$ dan ${ }^{60} \mathrm{Co}$, pada Identifier GR-135 plus. GR-135 dapat menampilkan berbagai jenis radionuklida, asalkan sudah terkalibrasi dan ada dalam librarynya.

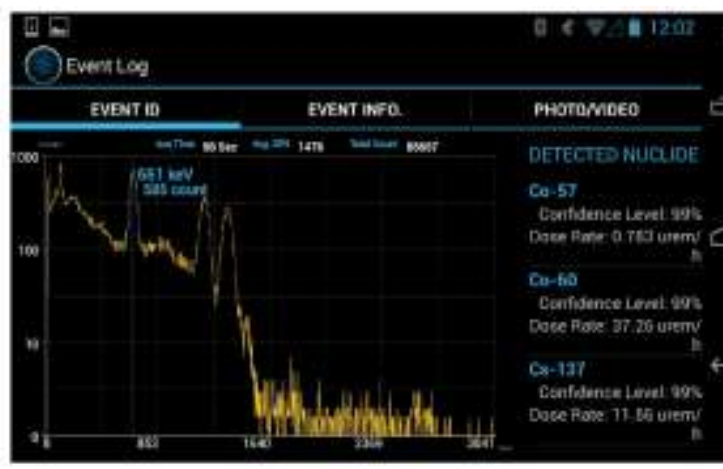

Gambar 9c. Tampilan ${ }^{57} \mathrm{Co},{ }^{60} \mathrm{Co}$, dan ${ }^{137} \mathrm{Cs}$ pada SAM-945

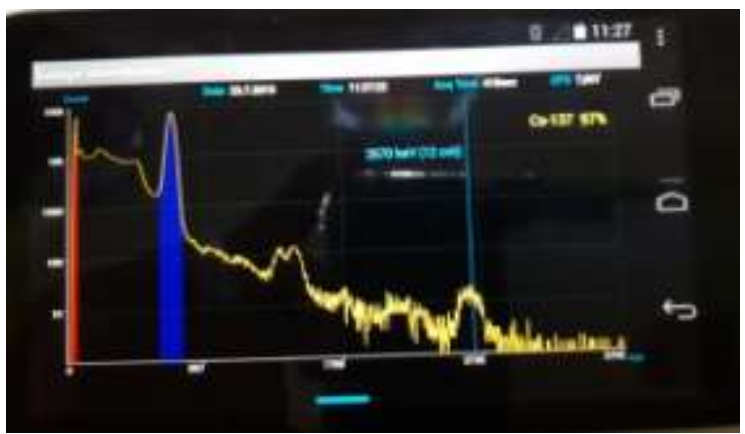

Gambar 9d. Tampilan ${ }^{241}$ Am pada SAM-945



Gambar 9e. Tampilan ${ }^{137}$ Cs pada InSpector 1000

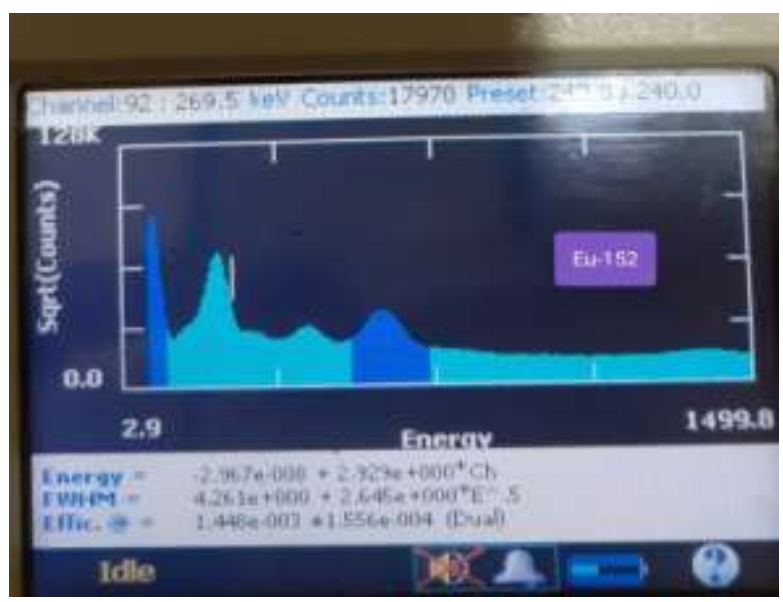

Gambar 9f. Tampilan ${ }^{152}$ Eu pada InSpector1000

Pada Gambar 9c disajikan tampilan ${ }^{57} \mathrm{Co}$, ${ }^{60} \mathrm{Co}$, dan ${ }^{137} \mathrm{Cs}$ pada SAM-945. SAM-945 dan pada Gambar 9d disajikan ${ }^{241}$ Am. SAM-945 mampu mengidentifikasi radionuklida tersebut dan radionuklida lainnya karena sudah terkalibrasi dan ada dalam librarynya. Kedua Identifier mampu mengidentifikasi jenis 
radionuklida asalkan ada dalam librarynya dan kandungannya melebihi background di sekitarnya. Pada Gambar 9e dan 9f disajikan tampilan ${ }^{137} \mathrm{Cs}$ dan ${ }^{152} \mathrm{Eu}$ pada InSpector 1000 . Dengan kemampuan mengidentifikasi ini, dapat diperoleh informasi untuk perhitungan kuantitatif dari jenis radionuklida yang terukur.

\section{KESIMPULAN}

Untuk mendapatkan harmonisasi pengukuran, pengukuran yang akurat, dan ketertelusuran, AUR (Identifier) harus dikalibrasi. Dengan dilakukannya kalibrasi (penentuan respon dan efisiensi), diperoleh hasil bahwa kurva hubungan antara laju cacah [cps] vs laju dosis ekivalen ambient $[\mu \mathrm{Sv} / \mathrm{h}]$ membentuk persamaan linier (Gambar 5a, 5b, dan 5c). Kurva hubungan antara laju cacah atau laju dosis terhadap SDD menurun secara eksponensial. (Gambar 6a, $6 \mathrm{~b}, \ldots \ldots .6 \mathrm{f})$. Kurva hubungan antara laju cacah atau laju dosis ekivalen terhadap invers kuadrat SDD membentuk persamaan linier (Gambar 8a, 8b, dan 8c). Respon dan Efisiensi Identifier SAM-945 lebih besar dibandingkan dengan InSpector-1000 dan GR-135 karena volume detektor Identifier SAM-945 lebih besar dari kedua identifier (Tabel 2). Dengan dilakukannya kalibrasi terhadap ketiga jenis Identifier diharapkan dapat diperoleh harmonisasi pengukuran, akurasi dan ketertelusuran.

\section{UCAPAN TERIMA KASIH}

Penulis mengucapkan terima kasih kepada PTKMR BATAN atas anggaran yang diberikan dalam menyelesaikan tugas litbang ini.

\section{DAFTAR PUSTAKA}

Exploranium $^{\mathrm{TM}}$ GR-135 The Identifier (2005), Radiation Identification Device, SAIC

Exploranium, Canada. Diakses dari www.saic.com/products/security. $\underline{\ln 1 \mathrm{~K}-}$ SS-C38987.pdf

(2006), GR-135G Plus System Manual Revision 1.0, SAIC Exploranium, 6108 Edwards Blvd, Mississauga, Ontario, Canada, L5T 2V7.

Guide ST 1.9, (2016), Radiation Practices And Radiation Measurements. ISBN 978 -952 -309-372-0 (pdf), Findland.
International Atomic Energy Agency- Safety Report Series-16 (2000), Calibration of Radioprotection monitoring instruments, Vienna, Austria.

ISO-17025 (2017), General requirements for the competence of testing and calibration laboratories, Vienna, Austria.

InSpector ${ }^{\mathrm{TM}} 1000$ (2017), Digital Hand-Held Multichannel Analyzer, Mirion Technologies, Canberra. diakses dari http://www.gammadata.se/assets/Uploads/

National Council on Radiation Protection and Measurements.No. 58 Second Edition (1986), A Handbook of Radioactivity Measurement Procedures Pub: NCRP Publications, 7910 Woodmont Avenue, Bethesda. Maryland, USA.

Nazaroh, (2010), Pedoman Pengukuran Laju Kerma Udara dan Kalibrasi alat Ukur Radiasi Tingkat Proteksi Serta Penilaian Ketidakpastiannya Berdasarkan The Measurement Good Practice Guide No. 49/2003, Jakarta, Jurnal Standardisasi vol, 12, Hal. $118-127$.

Nazaroh dan Sunaryati, S.I., (2016), Kalibrasi Alat Ukur Radiasi (AUR) Dan Kajian Terhadap Hasil Kalibrasi Monitor Area Medil Smart (MS91-MS94) Periode 20092015, PDIPTN, Yogyakarta, Prosiding

Peraturan Kepala BAPETEN No. 1 (2006), Laboratorium Dosimetri, Kalibrasi Alat Ukur Radiasi (AUR) dan Keluaran Sumber Radiasi Terapi, dan Standardisasi Radionuklida, Jakarta, BAPETEN..

Peraturan Kepala BATAN No.1 (2013), Organisasi dan Tata Kerja Badan Tenaga Nuklir Nasional, Jakarta, BATAN.

Peraturan Kepala BAPETEN No 4 tahun (2013), Proteksi dan Keselamatan Radiasi Dalam Pemanfaatan Tenaga Nuklir,. Jakarta, BAPETEN.

Susilowati, P., Pratiwi, S.W., Susilo,D., (2011), Pengukuran Laju Dosis, Paparan Radiasi Sekunder Sinar-X Di Ruangan Dan Lingkungan Sekitar Instalasi Radiologi, Studi Kasus: Ruang Radiologi Poliklinik Fakultas Kedokteran, Fisika Mulawarman, Vol.7 No.2.

SAM 945 (2016), Portable Isotope Identifier Instruction Manual, Berkeley Nucleonics Corporation, diakses dari www.berkeleynucleonics.com, Canbera. 
